\title{
Learning Physics with Worksheet Assisted Augmented Reality: The Impacts on Student's Verbal Representation
}

\author{
Azizah Ainun Nuha ${ }^{1, *}$ Heru Kuswanto ${ }^{2}$, Ernita Apriani ${ }^{1}$, Wilis Putri Hapsari ${ }^{2}$ \\ ${ }^{I}$ Master of Physics Education, Faculty of Mathematics and Natural Science, Universitas Negeri Yogyakarta, \\ Indonesia \\ ${ }^{2}$ Department of Physics Education, Faculty of Mathematics and Natural Science, Universitas Negeri Yogyakarta, \\ Indonesia \\ ${ }^{*}$ Corresponding author. Email:azizahainun.2019@student.uny.ac.id
}

\begin{abstract}
This study aims to describe the effect of worksheets assisted by Augmented Reality on students' verbal representation abilities. This type of research is a pre-experimental study with a comparative design of all groups. This research was conducted in class XI MIA 1 as the experiment class and class XI MIA 3 as the control class. Data collection methods are observation and test methods. The data analysis technique in this study used the MannWhitney $U$ test analysis. The $U$ test analysis results showed a significant difference from the learning treatment with worksheets assisted augmented reality. This shows that worksheets assisted by Augmented Reality is effectively used to improve students' verbal representation ability.
\end{abstract}

Keywords: Augmented reality, Students' worksheet, Verbal representation

\section{INTRODUCTION}

Education is an effective medium for building each individual's character and skills [1][2]. The dynamic learning process has contributed to students' preparation to face the challenges of an increasingly complex and impactful world [3]. Character training and ideas or knowledge requires a fair communication process. The role of educators greatly influences this condition in conveying ideas to students. Good communication intends to play an active role during the classroom's learning process to create effective learning.

Students' ability to understand the material concept well is said to succeed in learning [4]. Students can understand the concept by interpreting the material continuously and not allowing information to be stored passively. Limited memory capacity requires students to have the ability to represent information or knowledge. Measurable but coherent representations with different modalities can support learning and assist the desired logical mental construction [5].

Physics learning is one of the main branches of science, including discussing aspects of indirect observation or tools or media. The data obtained through the observation process can be analyzed to have a particular meaning or understanding. Translation or representation of data so that it is meaningful plays an important role. Representation plays a role in understanding concepts to solve a problem [6]. How to report and express trends in data and show the relevance of the data obtained with the theory are the intended solutions [5].

Various representations are fair, depending on the context and content in explaining an idea or ideas. Types of representation are generally divided based on the desired form of information, namely verbal, graphic, graphic, and mathematical [7][8]. The process of representing can also develop and optimize students' thinking skills as a form of construction and abstraction of knowledge [9]. Translating the results of students' thoughts in learning can generally take to be done verbally. Good verbal skills have skills that require familiarity with written and spoken language [10]. The goal is to listen, examine the content, dare to express ideas, ideas, opinions, and thoughts so that the student can draw an appropriate conclusion. An essential aspect of verbal representation is related to the ease with which the text understands. 
There are 4 (four) characteristics of written or spoken texts that must meet to encourage learning [11]. The first is simplicity; that is, sentences must contain formulas briefly, and complicated words and phrases should avoid. Second, the text must arrange concerning the organization, and the internal and external structures must be visible. Third, the summary, the sentence must be short and precise. The four texts must support several types of motivationaffective stimulation in arousing the interest of students. The ability to represent verbal is not only for communication skills but also for reasoning, expressing thoughts, curiosity, and opinions [5]. Linearity test research proves that there is an effect of verbal ability on students' critical thinking skills [10].

Analysis of students' verbal representation ability in physics material study with indicators to understand vocabulary and word relations are related to the concept of getting a good score [12]. However, further analysis found that, on average, students had difficulty representing ideas/ideas and objects of observation verbally. It can see in selecting models, steps for solving, and errors in distinguishing concepts caused by not understanding the problem [13]. Support for other findings shows that learners focus on solving math questions without verbally defining them [14][15]. In observing activities, students often use literature to represent objects. Even though verbally representing related to the facts and concepts learned can help analyze and assess learning understanding [16]. Students tend to follow examples of the teacher's answers, not write based on what they understand correctly.

A significant finding in developing Student Worksheet (LKPD) can improve verbal representation skills [17]. The form of student worksheet files as a means of learning in print or not always using as an alternative in teaching and learning activities. The students' worksheet can help students understand the material and provide extensive opportunities to demonstrate knowledge and develop high-level skills [18]. Student worksheet in several studies allows learning activities that foster curiosity, thinking skills, and communication skills [19]. Learning with LKPD that involves visual, oral, mental, and writing skills can support students in learning science [10]. The visualization of activities usually displayed in the student worksheet is in the form of a 2-dimensional picture equipped with a narrative. The visualization that can improve students' skills are abstract visualization that allows students to manipulate and explore images.

However, currently, the implementation of learning is hampered by the COVID-19 pandemic. The government's decision is related to the Ministry of Education and Culture Circular No. 4 of 2020 concerning online / distance learning implementation. It issue as a form of anticipation of the spread of the virus. It was detected to come from Wuhan, China, a new virus (Covid-19) emerged [20]. WHO's data shows that Covid-19 has become a global pandemic with $5,817,385$ confirmed positive cases from more than 200 countries in the world (update: 30-05-2020). All social lines, including education, are not ready to face this situation. Extraordinary confinement situations impact students to be vulnerable to loss of social references, contact with peers, and access to resources [21]. Technological developments present the latest innovations expected to optimize the student learning process; in this case, current student worksheets.

Renewable research innovations in education are quite diverse, one of which is augmented reality. Augmented reality, as of today's technology with virtual information that can see in real-time equip with digital information. Users can feel the world interacting with 3-dimensional objects through realtime calculations from the position parameters and computer camera angles [22]. The reader only needs to scan the physical book's code or image to display each marker's 3-dimensional model quickly.

Educational research, both from abroad and within the country that develops AR technology, has presented several benefits, improving teaching quality in the classroom [23]. Other studies have also stated that learning using augmented reality technology in grade 7 is fun, easy, and useful [24]. Thus increasing motivation and interaction with peers [25]. Teachers can use augmented reality as interactive learning media in visualizing material in real-time [26]. Adult IT-based learning has now become a demand that needs to implement and developed better.

AR-assisted students' worksheet research developed to make it easier for students to learn [27]. Student worksheet equipped with AR can combine models and simulations in the real world. It is essential for physics learning material because not all can be explained in real terms, so AR technology is needed. The role of AR in students' worksheet can support the higher-order thinking skills of students in physics practicum [28]. However, there is still not much research on its effect on verbal representation skills.

The material used in this study is an optical instrument, especially binoculars. The concept presented in 3D expects to clarify students' understanding to affect students' verbal representation ability. This problem encourages to know the effect of students' worksheet assisted by Augmented Reality on students' verbal representation on optical instrument material (binoculars). 


\section{RESEARCH METHODS}

This type of research is pre-experimental research. The research design used was the Intact Group Comparison Design, while the scheme is shown in Table 1.

Tabel 1. Schematic of intact group comparison design

\begin{tabular}{|c|c|c|}
\hline Group & Treatment & Post-Test \\
\hline Experiment & $\mathrm{X}$ & $\mathrm{O}_{1}$ \\
\hline Control & & $\mathrm{O}_{2}$ \\
\hline
\end{tabular}

The research was conduct at SMAN 1 Kalasan, Yogyakarta. This study used two samples of class XI, with a total of 50 students. XI MIA 1 class is the experimental class, and class XI MIA 3 as the control class. The data collection methods in this research are observation and test. The indicators used to determine the verbal representation abilities of students show in Table 2.

The data analysis technique in this study used the Mann-Whitney U test with the SPSS program's help. This analysis was used to determine the differences in the treatment given to the experimental class and the control class. The treatment is in the form of learning using augmented reality assisted student worksheet to verbal representation skills.

\section{RESULTS AND DISCUSSION}

The research conducts to determine student worksheet-assisted augmented reality on students' verbal representation ability. This research initially plans for direct or offline learning. The use of students' worksheet assisted by augmented reality in physics learning at SMA Negeri 1 Kalasan is relatively new and requires clear directions to use optimally. However, its implementation has hampered by the COVID-19 pandemic.

Limitations in the field due to the COVID-19 pandemic necessitate a change in research strategy. The application of learning that was initial face-to-face must change to face-to-face or online learning. In this study, online learning carries out with the Google Classroom platform on Optical Equipment material, especially binoculars.

Tabel 2. Verbal representation indicator

\begin{tabular}{|l|l|}
\hline Indicator of Verbal Representation & Indicator Problem \\
\hline Describe the problem in detail and clearly. & $\begin{array}{l}\text { Students can explain the problems found in detail and clearly } \\
\text { about life-related problems to the use of binoculars. }\end{array}$ \\
\hline Explain the definition and terms of a concept. & Students can explain the concept of refraction in binoculars. \\
\hline $\begin{array}{l}\text { Describe the results of mathematical } \\
\text { representations, diagrams, and graphs in the } \\
\text { form of verbal representations. }\end{array}$ & $\begin{array}{l}\text { Students can explain the results of graphical and mathematical } \\
\text { representations of the formation of images on binoculars in the } \\
\text { form of verbal representations. }\end{array}$ \\
\hline
\end{tabular}

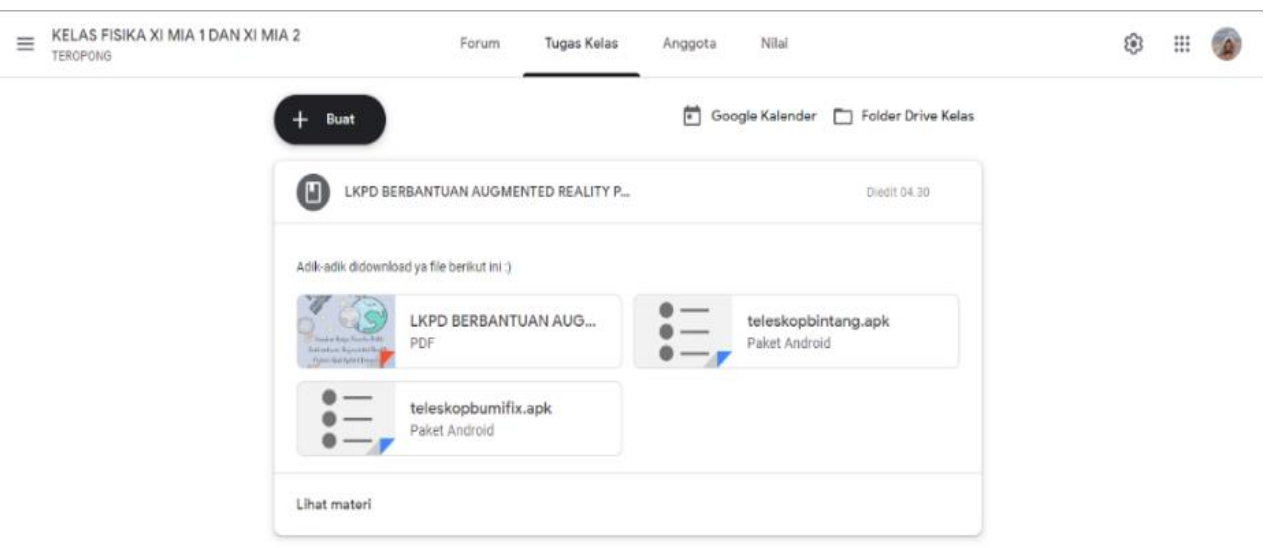

Figure 1. Components of experiment class teaching materials (XI MIPA 1) on the google classroom platform 


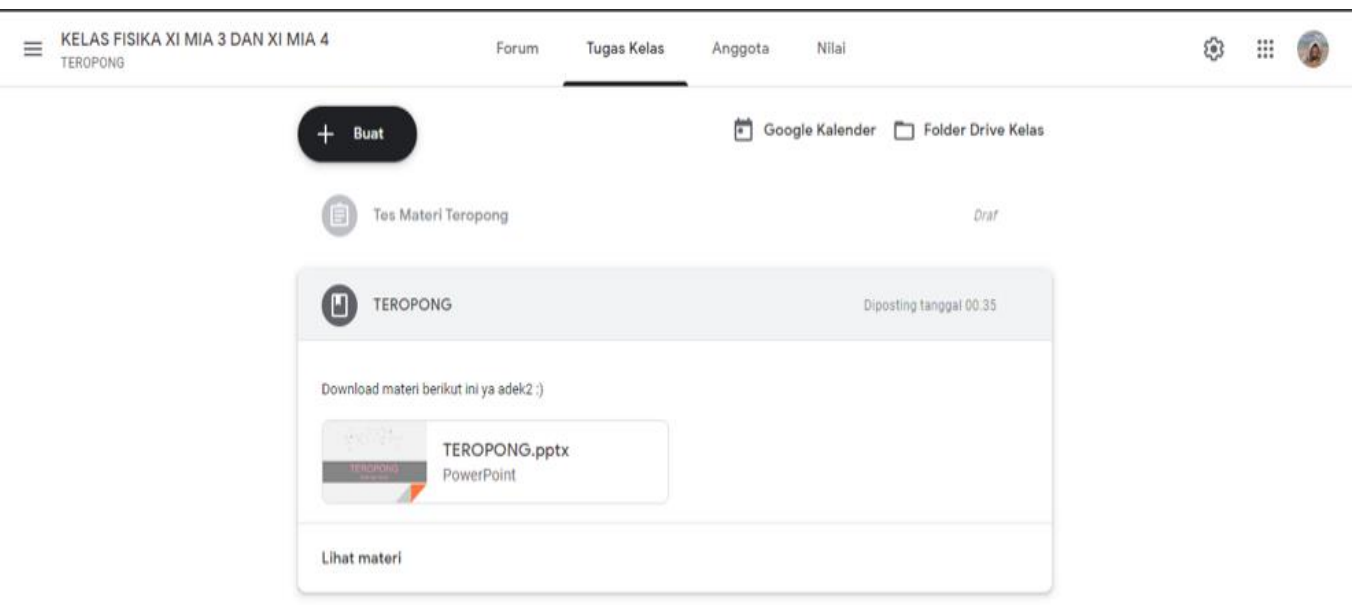

Figure 2. Components of control class teaching materials (XI MIPA 3) on the google classroom platform

Figure 1 shows the material teaching components for class XI MIA 1 show in one student worksheet and two augmented reality objects. Whereas in Figure 2, the material teaching components for class XI MIA 3 are in the form of powerpoints that adjust physics learning in general in schools during a pandemic. Teaching materials give to students after delivering brief material to each class. Learning with students' worksheet helped augmented reality in the experimental class, including a guidebook to help students understand students' worksheet optimally. Figure 3 shows the inside of the students' worksheet assisted by augmented reality on instructions for use.
This augmented reality-assisted students' worksheet can operate if students follow the instructions for use well. The image in the students' worksheet functions as a marker that will integrate with augmented reality information [29]; in this study, it is a $3 \mathrm{D}$ binocular object. The procedure carries out by pointing the android smartphone camera that has been integrated with the augmented reality application at the marker at the student worksheet. Scanning on markers can do offline, so there is no need for an internet network. The augmented reality display on the smartphone looks like Figure 4.
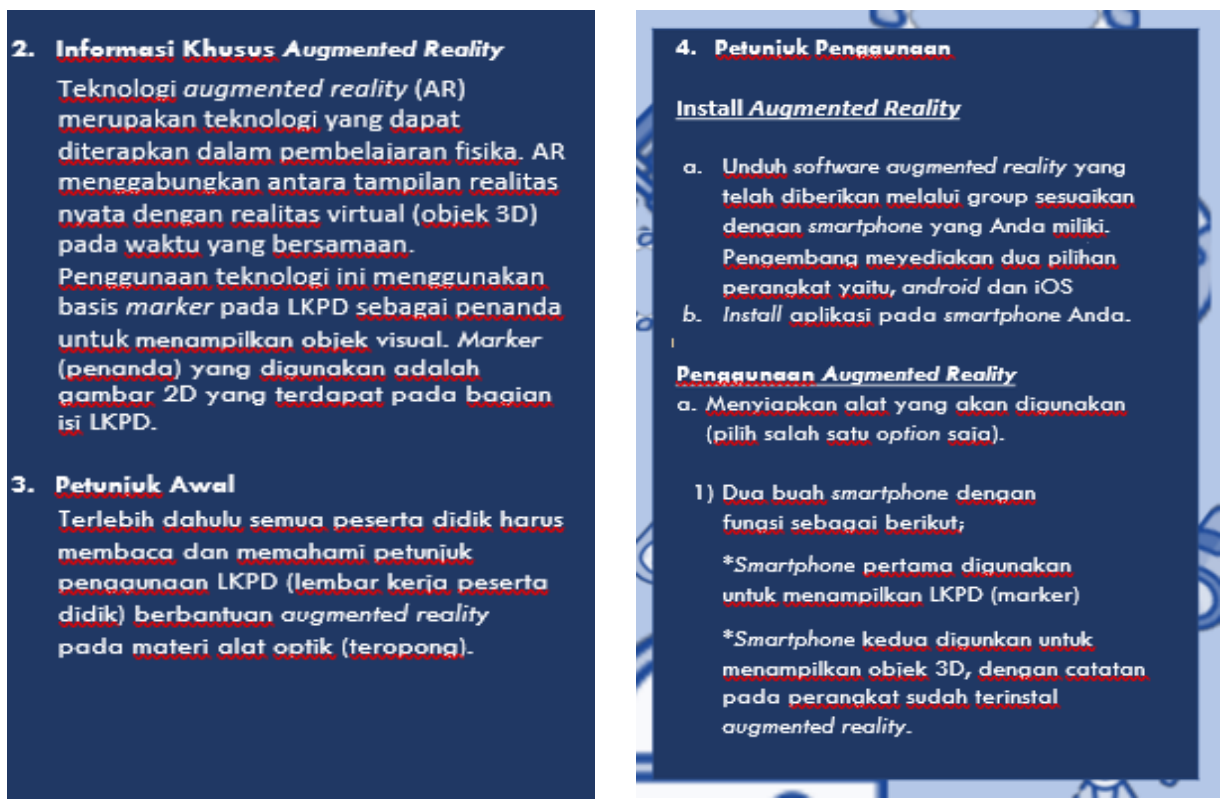

Figure 3. The section in the instructions for the use of students' worksheet assisted by augmented reality 


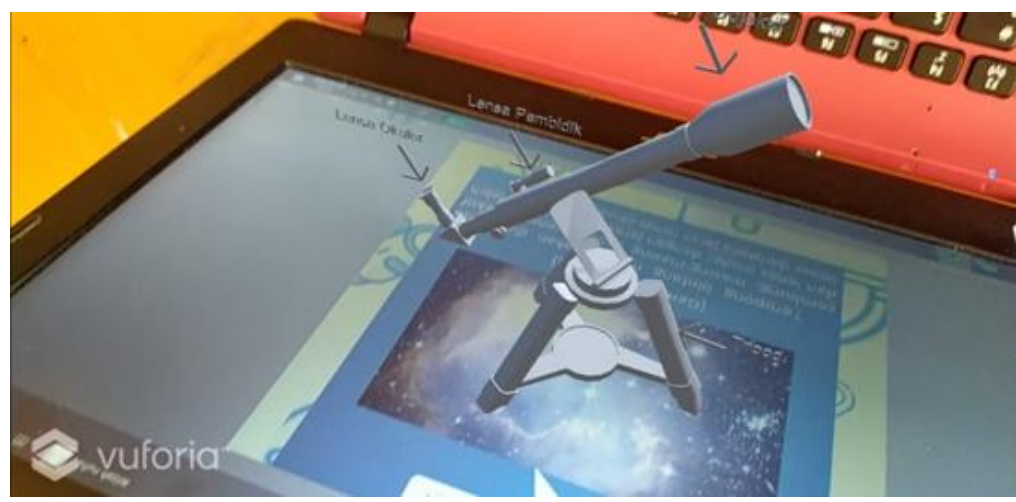

Figure 4. Display of augmented reality on a smartphone

Figure 4 shows that the appearance of the object, according to the marker, seems less appropriate. There was an error in placing the object on the marker used in learning. However, this does not diminish the essence of the content in question. The instruction given to students is to rotate the smartphone camera following clearly legible objects. In the next step, after scanning the marker, students were asked to work on several questions related to verbal representation skills. The treatment carries out to determine the effect of students' worksheet assisted by augmented reality on students' verbal representation ability. The ability of verbal representation is the basis for supporting various competencies needed by students, one of which is communication competence.

The verbal representation ability of students in this study was assessed based on 3 (three) indicators. Data on the difference in the mean score of the experimental and control classes for each verbal representation ability indicator show in Figure 5.

Data collection for the first indicator describes the problem in detail and clearly. The average score obtained by the experimental class was 22.35 , while the control class was 20.42. In this indicator, students ask to explain a problem in life-related to binoculars in detail and clearly. The second indicator explains the definition and terms of a concept. The experimental class average score was 11.62 , while the control class was 7.00. In this indicator, students ask to explain the concept of refraction in binoculars. The third indicator's data collection explains the results of mathematical representations, diagrams, and graphs in verbal representations. The experimental class average score was 5.50, while the control class was 6.08. In the third indicator, students ask to explain the results of a mathematical representation of the formation of images on binoculars.

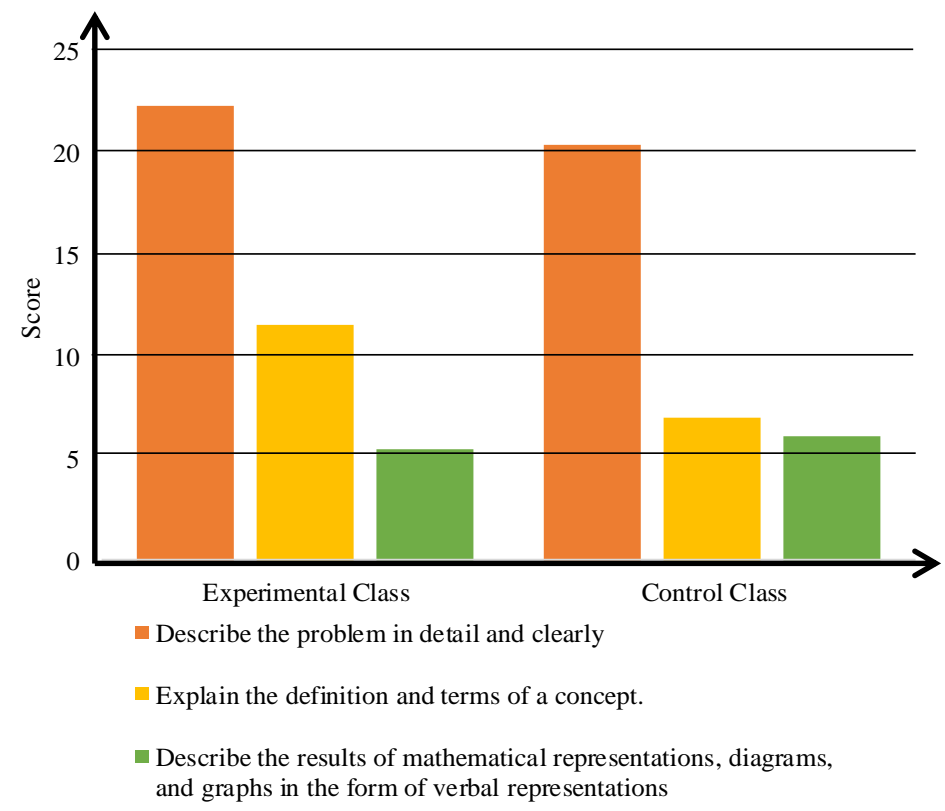

Figure 5. Average Score of Verbal Representation Ability Indicator 
Data collection for the first indicator describes the problem in detail and clearly. The average score obtained by the experimental class was 22.35 , while the control class was 20.42. In this indicator, students ask to explain a problem in life-related to binoculars in detail and clearly. The second indicator explains the definition and terms of a concept. The experimental class average score was 11.62 , while the control class was 7.00. In this indicator, students ask to explain the concept of refraction in binoculars. The third indicator's data collection explains the results of mathematical representations, diagrams, and graphs in verbal representations. The experimental class average score was 5.50, while the control class was 6.08. In the third indicator, students ask to explain the results of a mathematical representation of the formation of images on binoculars.

The data in Figure 5 interpret that there are differences in students' verbal representation abilities based on the treatment given. The experimental class excels at the indicators explaining the problem in detail and clearly, also at the indicators explaining the definition and terms of a concept. However, the indicators explain the results of mathematical representations, diagrams, and graphs in verbal representations; the control class is superior. Also, the lowest average score for both classes obtains on the third indicator. Students are more focused on solving math questions; a similar explanation obtains in previous studies [14].

This study produces quantitative data, with the analysis of the U test or the Mann Whitney U-Test. Utest analysis uses a random sample drawn from the same population to determine the differences between two populations [30]. The $U$ test analysis is an alternative to the parametric T-test if the T test's presumptions do not meet.

Table 3. Normality test

\begin{tabular}{|c|c|c|c|c|c|c|c|}
\hline & \multicolumn{4}{|c|}{ Kolmogorov-Smirnov $^{2}$} & \multicolumn{3}{c|}{ Shapiro-Wilk } \\
\hline & Treatment & Statistic & df & Sig. & Statistic & df & Sig. \\
\hline \multirow{2}{*}{ Value } & 1 & .310 & 25 & .000 & .803 & 25 & .000 \\
\cline { 2 - 8 } & 2 & .194 & 25 & .016 & .922 & 25 & .056 \\
\hline
\end{tabular}

The normality test in Table 3 shows the sig value in the Kolmogorov and Shapiro-Wilk test $<0.05$, which means that the data not normally distributed.
This assumption is correct to be continued in the $\mathrm{U}$ test analysis.

Table 4. Homogeneity test

\begin{tabular}{|l|l|l|l|l|l|}
\hline \multicolumn{2}{|c|}{ Value } & Levene Statistic & df1 & df2 & Sig. \\
\cline { 2 - 6 } & Based on Mean & 2.651 & 1 & 48 & .110 \\
\cline { 2 - 6 } & Based on Median & 2.912 & 1 & 48 & .094 \\
\cline { 2 - 6 } & Based on Median and with adjusted df & 2.912 & 1 & 45.070 & .095 \\
\cline { 2 - 6 } & Based on trimmed mean & 2.613 & 1 & 48 & .113 \\
\hline
\end{tabular}

The homogeneity test in Table 4 shows the sig value. $0.110>0.05$, which means that the variance of the two groups is the same or homogeneous. This assumption is correct and has fulfilled the U-test analysis. The hypothesis proposed in this study is that Ha defines as the difference in posttest data between the experimental class (XI MIA 1) and the control (XI MIA 3). The basis for the decision-making hypothesis $\mathrm{Ha}$ is accepted, if the significance value or Asymp. Sig. (2-tailed) is smaller than probability 0.05 . The results of the u-test (Mann-Whitney) using the IBM Table 5. Mann-Whitney SPSS output

\begin{tabular}{|l|r|}
\hline Mann-Whitney U & 191.000 \\
\hline Wilcoxom & 516.000 \\
\hline Z & -2.444 \\
\hline Asymp. Sig. (2-tailed) & .015 \\
\hline
\end{tabular}


Table 5 shows that the significance value is 0.015 $<0.05$. As the basis for the u-test decision making, this information can conclude that $\mathrm{Ha}$ is accepted. So it can be said that there is a significant difference between the sample and the treatment given. Worksheets assisted with Augmented Reality is more influential in increasing students' verbal representation in the experimental class than the control class, which is not given the worksheets.

\section{CONCLUSIONS AND SUGGESTIONS}

Education as an effective medium for shaping individual character is dynamic in line with ongoing developments. The world today is in a situation or state that demands online / distance learning. The results showed that the experimental class score indicator (XI MIA 1) was superior to the control class (XI MIA 3). The experimental class treatment has the effect of increasing the students' verbal representation ability compared to the control class. Worksheets assisted with augmented reality can be an alternative teaching material that has an impact on verbal representation. Teaching materials are designed for formal learning but can also be applied to online learning with some adaptations.

\section{REFERENCES}

[1] I.W. Redhana, Mengembangkan Keterampilan Abad Ke-21 Dalam Pembelajaran Kimia, Jurnal Inovasi Pendidikan Kimia 13(1) (2019) 2239.

[2] W. Suastra, Model Pembelajaran Fisika untuk Mengembangkan Kreativitas Berpikir dan Karakter Bangsa Berbasis Kearifan Lokal Bali, JPI Jurnal Pendidikan Indonesia 2(2) (2013) 221-235. DOI: http://dx.doi.org/10.23887/jpiundiksha.v2i2.2166

[3] M.W. Meyer, D. Norman, Changing Design Education for The 21st Century, She Ji 6(1) (2020) 13-49. DOI: http://dx.doi.org/10.1016/j.sheji.2019.12.002

[4] H. Georgiou, M.D. Sharma, Does Using Active Learning in Thermodynamics Lectures Improve Students' Conceptual Understanding and Learning Experiences?, European Journal of Physics 36(1) (2015). DOI: http://dx.doi.org/10.1088/0143$\underline{0807 / 36 / 1 / 015020}$

[5] P. Morten Kind, A. Carl, Ø. Guttersrud, Multiple Representations in Physics and Science Education, Multiple Representations in Physics Education, vol. 10, Springer, Berlin, Heidelberg,
2017, pp. 1-21. DOI: http://dx.doi.org/10.1007/978-3-319-58914-5

[6] A. Fithrathy, Ariswan, Developing physics learning multimedia to improve graphic and verbal representation of high school students, Journal of Physics: Conference Series, vol. 1233, IOP Publisher, Bristol, 2019, pp. 1-10. DOI: https://iop.org/10.1088/17426596/1233/1/012071

[7] A. P. Bal, Skills of using and transform multiple representations of the prospective teachers, Procedia - Social and Behavioral Sciences, vol. 197, Elvesier, Greece, 2015, pp. 582-588. DOI: http://dx.doi.org/10.1016/j.sbspro.2015.07.197

[8] Selamet, I. K. Mahardika, B. Supriadi, Analisis kemampuan representasi verbal, matematika, gambar dan grafik (R-VMGG) siswa SMAN pasirian pada materi termodinamika, Seminar Nasional Pendidikan Fisika 3, Universitas Negeri Jember, Jember, 2017, pp. 144-148.

[9] D. Rahmawati, P. Purwanto, S. Subanji, E. Hidayanto, R.B. Anwar, Process of mathematical representation translation from verbal into graphic, International Electronic Journal of Mathematics Education 12(4) (2017) 367-381.

[10] A. Irawan, G. Kencanawaty, Peranan Kemampuan Verbal dan Kemampuan Numerik terhadap Kemampuan Berpikir Kritis Matematika, AKSIOMA Journal of Mathematics Education 5(2) (2017) 110. DOI: http://dx.doi.org/10.24127/ajpm.v5i2.669

[11] P. Hubber, R. Tytler, Enacting a Representation Construction Approach to Teaching and Learning Astronomy. eds. D.F. Treagust et al., in: Multiple Representations in Physics Education, Springer, Berlin, 2017, pp. 141-2 DOI: $\quad$ http://dx.doi.org/10.1007/978-3-319$\underline{58914-5 \quad 7}$

[12] A.Y.R. Wulandari, Analisis kemampuan verbal siswa pada materi, Prosiding SENCO, Universitas Trunojoyo Madura, Madura, 2018, pp. 23-29.

[13] H. Handayani, Analisis Kemampuan Representasi Siswa Pada Materi Volume Kubus dan Balok di Sekolah Dasar, Journal of Madrasah Ibtidaiyah Education 3(1) (2019) 48-61. DOI: http://dx.doi.org/10.32934/jmie.v3i1.97

[14] S.R. Indra, I.K. Mahardika, B. Supriadi, Pengaruh model pembelajaran kooperatif tipe 
nht disertai virtual-lab terhadap kemampuan representasi verbal dan gambar siswa dalam pembelajaran fisika kelas $\mathrm{X}$ di SMA jember (pada pokok bahasan momentum linier), Seminar Nasional Pendidikan Fisika, vol. 2, Universitas Negeri Jember, Jember, 2017, pp. 1-6.

[15] R. Ekawati, A. Setiawan, R.A. Wulan, D. Rusdiana, The use of classroom assessment based on multi-representation ability in mechanics concept the use of classroom assessment based on multi- representation ability in mechanics concept, Journal of Physics: Conference series, vol. 1157, IOP Publisher, Bristol, 2019, pp. 1-4. DOI: $\underline{10.1088 / 1742-}$ $\underline{6596 / 1157 / 3 / 032061}$

[16] S. Ladisa, A. Rahmat, Hubungan Kemampuan Representasi Visual dan Representasi Verbal Mahasiswa Pada Praktikum Morfologi Tumbuhan, SIMBIOSA 9(1) (2020) 60-67. DOI: http://dx.doi.org/10.33373/sim-bio.v9i1.2430

[17] I.I.H. Nur, Wasis, Penerapan Lembar Kerja Peserta Didik (LKPD) Berbasis Pictorial Riddle untuk Melatihkan Kemampuan Representasi, Jurnal Inovasi Pendidikan Fisika 7(2) (2018) 221-226.

[18] D. Purnamawati, C. Ertikanto, A. Suyatna, Keefektifan Lembar Kerja Siswa Berbasis Inkuiri untuk Menumbuhkan Keterampilan Berpikir Tingkat Tinggi, Jurnal Ilmiah Pendidikan Fisika Al-BiRuNi 6(2) (2017) 209219. DOI: $\quad$ https://doi.org/10.24042/jipfalbiruni.v6i2.2070

[19] M. Fuadati, I. Wilujeng, Web-Lembar Kerja Peserta Didik IPA Terintegrasi Potensi Lokal Pabrik Gula untuk Meningkatkan Rasa Ingin Tahu Peserta Didik, Jurnal Inovasi Pendidikan IPA 5(1) (2019) 98-108. DOI: https://doi.org/10.21831/jipi.v5i1.24543

[20] A. Lee, Wuhan Novel Coronavirus ( COVID-19 ): Why Global Control is Challenging?, Public Health 179 (2020) A1-A2. DOI: https://doi.org/10.1016/j.puhe.2020.02.001

[21] J. Cifuentes-faura, The Role of Social Work in The Field of Education during Covid-19, International Social Work (2020) 1-3. DOI: https://doi.org/10.1177/0020872820944994

[22] Y. Zhang, W. Zhang, A Study on Narrative Design of Augmented Reality Publications, Springer International Publishing, 2018, pp.
373-381. DOI: https://doi.org/10.1007/978-3319-95270-3 31

[23] J. M. S. García, P. T. Morales, Flipped Classroom/Converging technologies for teaching: Augmented Tecnologías convergentes para la enseñanza: Realidad Aumentada, BYOD, Flipped Classroom Converging technologies for teaching: Augmented Reality, BYOD, Flipped Classroom, RED. Revista de Educación a Distancia, 2017, pp.1-15. DOI: http://dx.doi.org/10.6018/red/55/8

[24] D. Karagozlu, F. Ozdamli, Student Opinions on Mobile Augmented Reality Application and Developed Content in Science Class, TEM Journal 6(4) (2017) 660-668. DOI: https://dx.doi.org/10.18421/TEM64-03

[25] K. Mumtaz, M. M. Iqbal, S. Khalid, T. Rafiq, S. M. Owais, M. Al Achhab, An E-Assessment Framework for Blended Learning with Augmented Reality to Enhance the Student Learning, EURASIA Journal of Mathematics Science and Technology Education 8223(8) (2017) 4419-4436. DOI: https://doi.org/10.12973/eurasia.2017.00938a

[26] Y. Daineko, M. Ipalakova, D. Tsoy, Development of Practical Tasks in Physics with Elements of Augmented Reality for Secondary Educational Institutions, International Conference on Augmented Reality, Virtual Reality and Computer Graphics, 2018, pp. 404412. DOI: https://doi.org/10.1007/978-3-31995270-3_34

[27] D. Muliyati, S. Viridi, E. Fitriani, D. Ambarwulan, Explain the physics concepts with flood phenomena using augmented reality technology Explain the Physics Concepts with Flood Phenomena Using Augmented Reality Technology, in: AIP Conference Proceedings, vol. 020009, AIP Publishing, College Park, Maryland, 2019, pp. 1-5. DOI: https://doi.org/10.1063/1.5132644

[28] F. Bakri, D. Sumardani, D. Muliyati, Integrating augmented reality into worksheets: Unveil learning to support higher-order thinking skills integrating augmented reality into worksheets : unveil learning to support higher-order thinking skills, in: AIP Conference Proceedings, vol. 020012, AIP Publishing, College Park, Maryland, 2019, pp. 1-7. DOI: https://doi.org/10.1063/1.5132647 
[29] B. Fauzi, E. Ervina, M. Dewi, Practice the higher-order thinking skills in optic topic through physics worksheet equipped with augmented reality practice the higher-order thinking skills in optic topic through physics worksheet equipped with augmented reality, in: AIP Conference Proceedings, vol. 020006, AIP Publishing, College Park, Maryland, 2019, pp. 1-8. DOI: https://doi.org/10.1063/1.5132647

[30] T. W. MacFarland, J. M. Yates, Chapter 4 Mann - Whitney U Test, Springer International Publishing, Switzerland, 2016. DOI: https://doi.org/10.1007/978-3-319-30634-6_4 